\title{
Modified Model of Sub-Critical Size Cranial Defect in the Rabbit
}

\author{
Modelo Modificado de Defecto Craneal de Tamaño Subcrítico de Conejo
}

"Marques, J. M.; **Viegas, C.; **'Dias, M. I.; "Zagalo, C.; *** Gomes, P.;

***: Fernandes, M. H.; ${ }^{* * * * *}$ Santos. J. D. \& ${ }^{* * * * * *}$ Cabrita, S. C.

\begin{abstract}
MARQUES, J. M.; VIEGAS, C.; DIAS, M. I.; ZAGALO, C.; GOMES, P.; FERNANDES, M. H.; SANTOS. J. D. \& CABRITA, S. C. Modified model of sub-critical size cranial defect in the rabbit. Int. J. Morphol., 28(2):525-528, 2010.

SUMMARY: In medical sciences, any experimental animal model should be reproducible and adequate to the purpose of simulated human physiological response. In bone injury response research, when bone substitutes are in use, it is of primary importance that studied defects fail to heal unless treated with the tissue engineering therapy under study. This failure defines the concept of "critical size defect" (CSD) wich has different limits according to the animal species used and the location of the defect. Although this is a basic concept, when the aim of the study is to investigate the interface Bone-Biomaterial, it is of primary importance to obtain as much contact area as possible. In order to do so, we propose a modified surgical approach to the classical bi-parietal round sub-critical defect model in rabbit vault.
\end{abstract}

KEY WORDS: Rabbit; Cranial vault; Trephine defect.

\section{INTRODUCTION}

It is well known that, in young growing individuals, the repair of trephine defects occurs more rapidly than in adults. This is true for any part of the skeleton and for every species, so, an experimental model in this area should only use skeletally adult animals to obtain patronized and reliable information. On the other hand, bone grafting can include the use of autografts, allografts, xenografts, and synthetically produced bone substitutes, that should be placed and stabilized in the defect area, in order to fulfil the bone healing objective.

In our study, we used a patented glass-reinforced hydroxyapatite, the Bonelike $\AA$, as a graft material. The cranial defects shape was adapted in order to fulfil the aims of the study. The concept of CSD is also, in experimental circumstances, correlated with the time of the experiment. This idea leads to the term "sub-critical", which is applicable to those defects that fail spontaneous healing during the patronized time of the experiment. Our objective is to provide as much interface "bone graft-structural bone" as possible lead by this modified technical approach.

\section{MATERIAL AND METHOD}

Twelve skeletally adult male New Zealand White rabbits were used in this study. Animals were fasted for 12 hours, but water was not withheld. Anaesthesia was induced with medetomidine $(0.15 \mathrm{mg} / \mathrm{kg} \mathrm{SC})$ and butorphanol $(0.1 \mathrm{mg} / \mathrm{kg} \mathrm{IM})$, and 15 minutes after the administration of this combination, by the slow injection of ketamine $(5 \mathrm{mg} /$ $\mathrm{Kg}$ IM or EV in the marginal ear vein). The anaesthesia was maintained by inhalation anaesthesia, after oral intubation with a small endotracheal tube, with isoflurane $(0.25 \%$ to $2 \%$ ) in an oxygen flow of 0.5 to $2 \mathrm{~L} / \mathrm{min} / \mathrm{kg}$ through an anaesthetic Mapleson A Magill breathing system. The anaesthetic status of each rabbit was monitored during the entire surgical period by a non-invasive pulse oximeter (respiratory frequency and oxygen saturation of haemoglobin), a capnograph (end-tidal carbon dioxide) and cardiac auscultation (heart rate). In the post-operative period, each animal was medicated with metilprednisolone $(8 \mathrm{mg} /$ $\mathrm{kg}$ IM, dose unique), to prevent the laryngeal edema and iatrogenic tracheitis, and with antibiotherapy, enrofloxacine $(5 \mathrm{mg} / \mathrm{kg}$ diluted SC, BID), during the first week after surgery.

* ISCS - Egas Moniz, Portugal.

** 3B's Research Group - Biomaterials, Biodegradables and Biomimetics, Department of Veterinary Sciences, University of Trás-os-Montes e Alto Douro, P.O. Box 1013, 5001-801 Vila Real, Portugal; Associated Laboratory - Institute for Biotechnology and Bioengineering, Portugal.

**** FMDUP, Portugal.

***** FEUP, Portugal.

****** FMUC, Portugal. 
The cranium was surgically reached through a sagital incision, with about $5 \mathrm{~cm}$ of length, above the sagital cranial suture, until touching the bone. After the dissection of the coetaneous plan, periosteum was split and spread, allowing the exposure of the bone. An 8mm trephine was used (in an appropriate surgical handpiece), and two round defects were created, bilaterally to biparietal bone suture. No other bone suture was touched. The drill was carefully performed in order to allow just the removal of the external surface of the cranial vault. Any irregularity was removed and the defects were washed with physiologic serum. Then, the right defect was kept unfilled, while the left defect was filled with previously hydrated Bonelike ${ }^{\circledR}$.

The surgical wound was then carefully closed, the periosteum with Vicryl 4-0 and the skin with Silkam 3-0, and the skin suture washed with iodopovidone.

This model is a modification of the well established sub-critical size defect model for cranial defects in rabbits (Albee, 1923; Holland, 1973; Hernández-Hofmann et al., 1984; Hollinger \& Kleinschmidt, 1990; Hollinger \& Winn, 1999; Albrektsson \& Johansson, 2001; Al Ruhaimi, 2001; Aldini et al., 2002; Holy et al., 2003; Abdul Razak et al., 2004; Alfaro et al., 2005; Bayne, 2005; Hollister et al., 2005; Alam et al., 2007), concerned for a maximum of 30 day experimental period.

The rabbits were euthanatized at the $30^{\text {th }}$ day of the experiment, through the administration of an overdose of sodium penthotal.
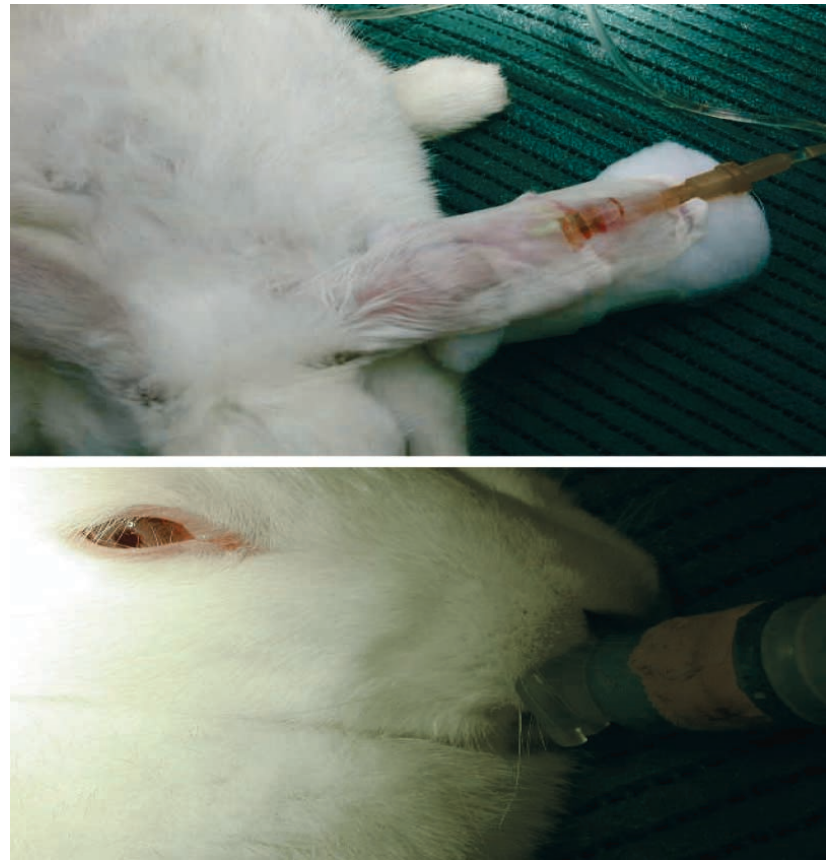

Fig. 1. Anaesthesia of the rabbit.

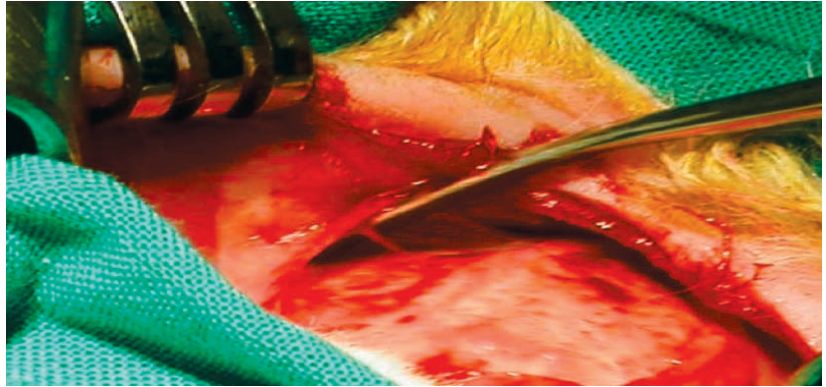

Fig. 2. Main incision and exposure of the cranial vault.

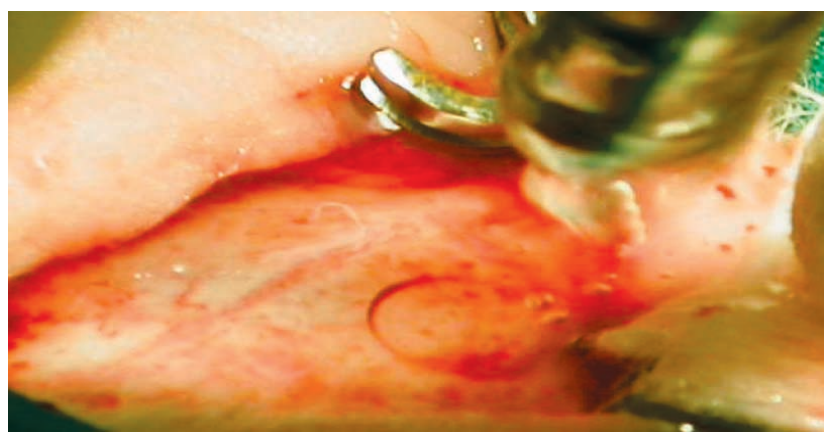

Fig. 3. Defect drilling.

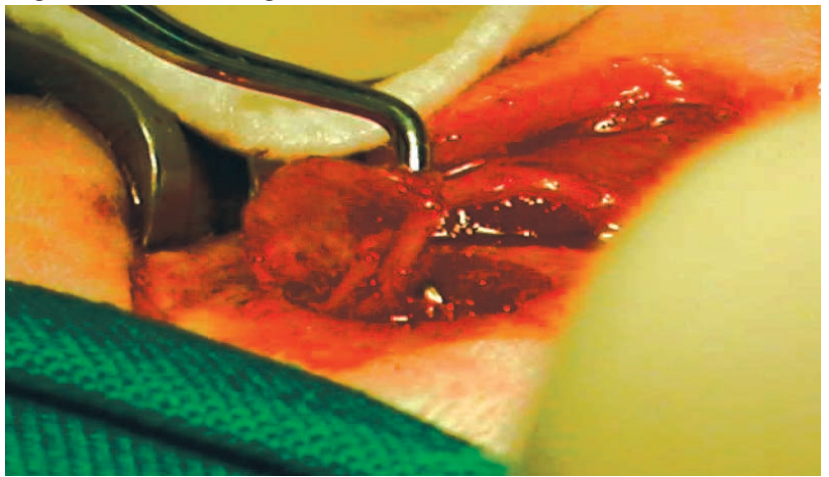

Fig. 4. Bone removal and clearance of the surgical site.
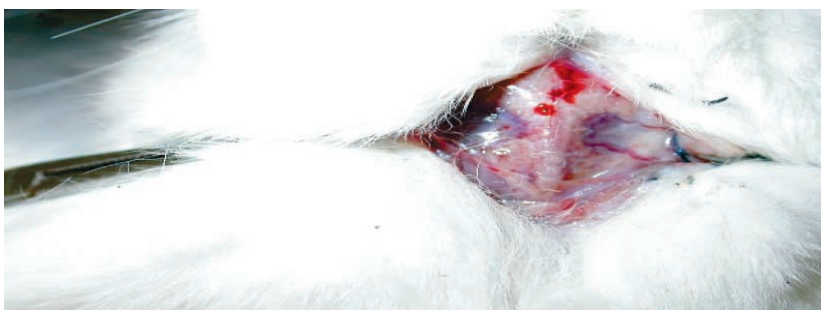

Fig. 5. Cranial vault surgical approach notice the fibrine membrane over the surgical site.

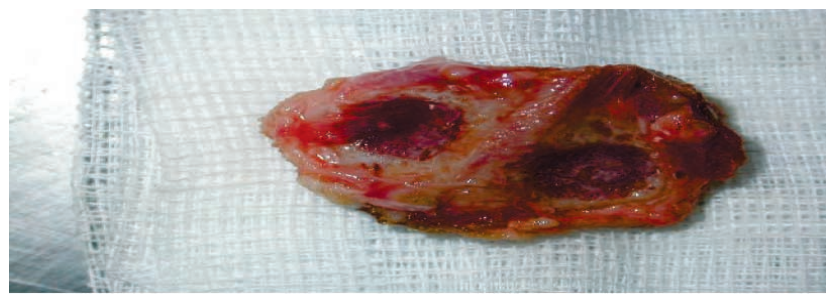

Fig. 6. Specimen. 


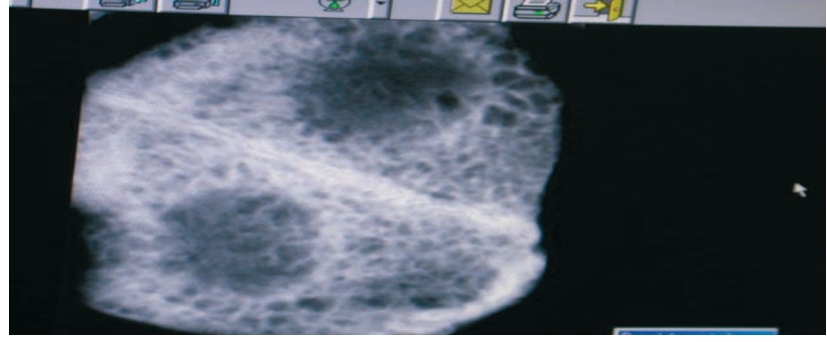

Fig. 7. X-Rayed specimen (notice irregular bone margin of the defect, showing the healing attempt ).

The surgical site was isolated and the cranial vault was approached. The bone was carefully removed, maintaining an extensive margin from the defects, in order to facilitate analyses and measurements.

The specimens were submitted to an X-Ray analysis (Trophy RVG-CCX dental device, France), and measured in order to determine the areas of the defects.

Each sample was measured with a proper device (Ecathom S7, Biomed, USA). Nine deepness circular measurement values were obtained for each sample.

\section{RESULTS}

The diameter of the defects $\mathrm{S} 1$ to $\mathrm{S} 12$ was $8 \mathrm{~mm}$. In Table I, deepness of the defects (mm).

Medium deepness obtained in the procedure: $h$ $=1,396 \mathrm{~mm}$; Variation, $\mathrm{v}=0,062 \mathrm{~mm}$.

Medium volume of the cavity : $(\mathrm{V}=\pi \mathrm{r} 2 \mathrm{~h}) ; \mathrm{V}=\pi(8 /$ 2) $2 \times 1.396, V=70,170 \mathrm{~mm}^{3}$.

Available contact surface: $2 \pi \mathrm{r}+\pi \mathrm{r} \sum . \mathrm{S}=2 \pi(8 / 2)+\pi(8 /$ 2) $)^{3}, \mathrm{~S}=75,398 \mathrm{~mm}^{3}$.

\section{DISCUSSION}

This model is a modification of the well established sub-critical size defect model for cranial defects in rabbits, concerned for a maximum 30 day experimental period.

The goal of this paper is to describe and propose an alternative approach to the classical experimental model, concerning to the obtainnance of a better and longer interface bone-implant.

The benefits we find in this modification towards the classical approach were:

- Severe augmentation of the interface area available for study, in each defect created.

- Absence of danger of perforation of the duramater, during the surgical procedure, and consequentially less morbidity.

For the experimental period in consideration (30 days) in rabbits, the concept "sub-critical size cranial defect" was maintained.

This method seems to be advantageous only when the objective is to study the interface "bone-biomaterial", and not the "de novo" tissue formation in the defect, because the very small deepness of the created defect in the rabbit vault. Although, was showed before, the effective volume of the defect is still considerable.

In conclusion, for this particular kind of study objective, the modified sub-critical size defect model for rabbit vault proved to be an acceptable option, and a guaranty of reliable experimental results.

Table II. Deepness of the defects (mm). Samples (S) 1 to 12.

\begin{tabular}{|c|c|c|c|c|c|c|c|c|c|c|c|c|}
\hline & S1 & $\mathbf{S 2}$ & S3 & S4 & S5 & S6 & S7 & S8 & S9 & S10 & S11 & S12 \\
\hline Medium & 1.426 & 1.388 & 1.399 & 1.389 & 1.384 & 1.390 & 1.399 & 1.412 & 1.421 & 1.422 & 1.399 & 1.401 \\
\hline \multirow[t]{9}{*}{ deepness } & 1.422 & 1.377 & 1.389 & 1.388 & 1.385 & 1.389 & 1.399 & 1.411 & 1.422 & 1.421 & 1.399 & 1.400 \\
\hline & 1.418 & 1.378 & 1.388 & 1.389 & 1.391 & 1.389 & 1.340 & 1.411 & 1.422 & 1.420 & 1.398 & 1.399 \\
\hline & 1.410 & 1.401 & 1.388 & 1.387 & 1.390 & 1.389 & 1.342 & 1.412 & 1.399 & 1.421 & 1.398 & 1.396 \\
\hline & 1.412 & 1.389 & 1.388 & 1.387 & 1.392 & 1.392 & 1.341 & 1.413 & 1.399 & 1.422 & 1.398 & 1.399 \\
\hline & 1.422 & 1.399 & 1.388 & 1.378 & 1.389 & 1.395 & 1.341 & 1.412 & 1.412 & 1.423 & 1.395 & 1.399 \\
\hline & 1.422 & 1.377 & 1.389 & 1.399 & 1.389 & 1.389 & 1.341 & 1.413 & 1.419 & 1.423 & 1.399 & 1.399 \\
\hline & 1.421 & 1.400 & 1.386 & 1.378 & 1.388 & 1.389 & 1.341 & 1.414 & 1.422 & 1.421 & 1.399 & 1.396 \\
\hline & 1.412 & 1.389 & 1.379 & 1.395 & 1.390 & 1.388 & 1.340 & 1.412 & 1.422 & 1.421 & 1.399 & 1.398 \\
\hline & 1.418 & 1.388 & 1.388 & 1.387 & 1.389 & 1.390 & 1.353 & 1.412 & 1.415 & 1.421 & 1.397 & 1.399 \\
\hline
\end{tabular}


MARQUES, J. M.; VIEGAS, C.; DIAS, M. I.; ZAGALO, C.; GOMES, P.; FERNANDES, M. H.; SANTOS. J. D. \& CABRITA, S. C. Modelo modificado de defecto craneal de tamaño subcrítico de conejo . Int. J. Morphol., 28(2):525-528, 2010.

RESUMEN: En las ciencias médicas, cualquier modelo animal de experimentación debe ser reproducible y ajustado al propósito de simular la respuesta fisiológica humana. En la investigación de la respuesta a la lesión ósea, cuando son utilizados sustitutos óseos, es de gran importancia el estudio de defectos que no logran sanar, a menos que sean tratados con terapia de ingeniería de tejidos. Este fracaso define el concepto de "defecto de tamaño crítico" (CDS) el cual tiene límites diferentes según la especie animal utilizada y la ubicación del defecto. Aunque se trata de un concepto básico, cuando el objetivo del estudio es investigar la interfaz hueso-biomaterial, es de primordial importancia obtener la máxima superficie de contacto que sea posible. Para ello, se propone una modificación en el enfoque quirúrgico del modelo clásico de defecto de tamaño subcrítico biparietal en la bóveda de conejo.

PALABRAS CLAVE: Conejo; Bóveda craneal; Defecto trépano.

\section{REFERENCES}

Abdul Razak, N. H.; Al-Salihi, K. A. \& Samsudin, A. R. An in vivo study of a locally-manufactured hydroxyapatitebased material as bone replacement material. Med. J. Malaysia, 59(B):119-20, 2004.

Alam, S.; Ueki, K.; Marukawa, K.; Ohara, T.; Hase, T.; Takazakura, D. \& Nakagawa, K. Expression of bone morphogenetic protein 2 and fibroblast growth factor 2 during bone regeneration using different implant materials as an onlay bone graft in rabbit mandibles. Oral Surg. Oral Med. Oral Pathol. Oral Radiol. Endod., 103(1):16-26, 2007.

Albee, F. H. Fundamentals in bone transplantation: experience in three thousand bone graft operations. JAMA, 81:1429-32, 1923.

Albrektsson, T. \& Johansson, C. Osteoinduction, osteoconduction and osseointegration. Eur. Spine J., 10(2):S96-101, 2001.

Aldini, N. N.; Fini, M.; Giavaresi, G.; Torricelli, P.; Martini, L.; Giardino, R.; Ravaglioli, A.; Krajewski, A.; Mazzocchi, M.; Dubini, B.; Ponzi-Bossi, M. G.; Rustichelli, F. \& Stanic, V. Improvement in zirconia osseointegration by means of a biological glass coating: An in vitro and in vivo investigation. J. Biomed. Mater. Res., 61(2):282-9, 2002.

Al Ruhaimi, K. A. Bone graft substitutes: a comparative qualitative histologic review of current osteoconductive grafting materials. Int. J. Oral Maxillofac. Implants, 16(1):105-14, 2001.

Bayne, S. C. Dental biomaterials: where are we and where are we going? J. Dent. Educ., 69(5):571-85, 2005.
Hernández-Alfaro, F.; Pages, C. M.; García, E.; Corchero, G. \& Arranz, C. Palatal core graft for alveolar reconstruction: a new donor site. Int. J. Oral Maxillofac. Implants, 20(5):777-83, 2005.

Hofmann, H.; Thieme, V.; Abendroth, K.; Schimke, E.; Zieger, M. \& Berger, G. Use of bioglass ceramic for alloplastic bone replacements in the maxillofacial region. 1. Studies on clinically oriented animal models. Zahn Mund. Kieferheilkd. Zentralbl., 72(6):531-40, 1984.

Holland, A. J. Laboratory animal anaesthesia. Can. Anaesth. Soc. J., 20(5):693-705, 1973.

Hollinger, J. O. \& Kleinschmidt, J. C. The critical size defect as an experimental model to test bone repair materials. J. Craniofac. Surg., 1(1):60-8, 1990.

Hollinger, J. O. \& Winn, S. R. Tissue engineering of bone in the craniofacial complex. Ann. N. Y. Acad. Sci., 875:37985, 1999.

Hollister, S. J.; Lin, C. Y.; Saito, E.; Lin, C. Y.; Schek, R. D.; Taboas, J. M.; Williams, J. M.; Partee, B.; Flanagan, C. L.; Diggs, A.; Wilke, E. N.; Van Lenthe, G. H.; Müller, R.; Wirtz, T.; Das, S.; Feinberg, S. E. \& Krebsbach, P. H. Engineering craniofacial scaffolds. Orthod. Craniofac. Res., 8(3):162-73, 2005.

Holy, C. E.; Fialkov, J. A.; Davies, J. E. \& Shoichet, M. S. Use of a biomimetic strategy to engineer bone. J. Biomed. Mater. Res. A, 65(4):447-53, 2003.

Correspondence to:

Silva Marques, J. M. ISCS-Egas Moniz PORTUGAL

Received: 09-09-2009

Accepted: 11-03-2010

Email:silva.marques2006@gmail.com 